Mappemonde

Revue trimestrielle sur l'image géographique et les

formes du territoire

$124 \mid 2018$

Varia

\title{
Habiter la ville. Spatialités urbaines du pigeon biset à Paris
}

Angela Casal

(2) OpenEdition

Journals

Édition électronique

URL : http://journals.openedition.org/mappemonde/375

DOI : 10.4000/mappemonde.375

ISSN : 1769-7298

Éditeur

UMR ESPACE

Référence électronique

Angela Casal, « Habiter la ville. Spatialités urbaines du pigeon biset à Paris », Mappemonde [En ligne], 124 | 2018, mis en ligne le 10 juillet 2018, consulté le 15 septembre 2020. URL : http:// journals.openedition.org/mappemonde/375

Ce document a été généré automatiquement le 15 septembre 2020.

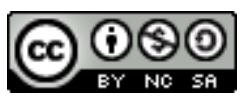

La revue Mappemonde est mise à disposition selon les termes de la Licence Creative Commons Attribution - Pas d'Utilisation Commerciale - Partage dans les Mêmes Conditions 4.0 International. 


\title{
Habiter la ville. Spatialités urbaines du pigeon biset à Paris
}

\author{
Angela Casal
}

Habiter la ville. Spatialités urbaines du pigeon biset à Paris

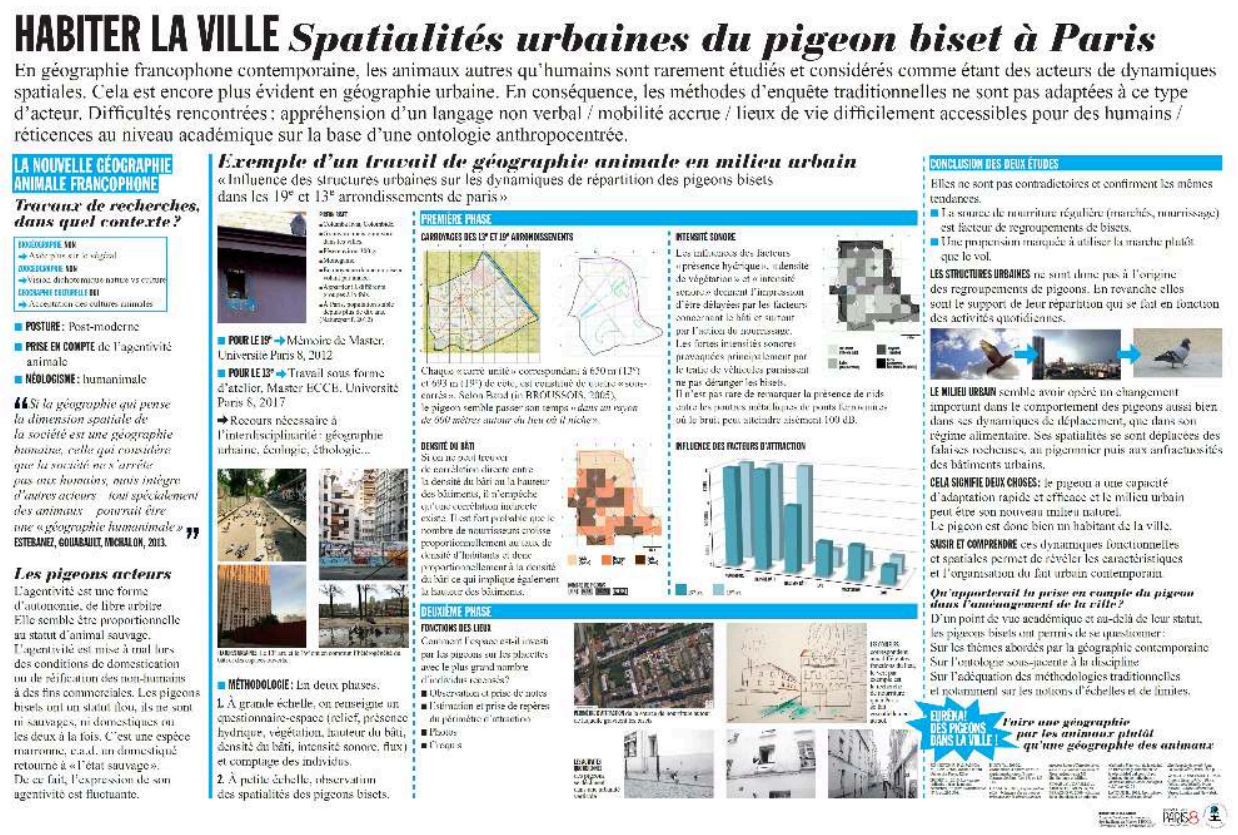

1 Le pigeon biset appartient à cet ensemble d'espèces commensales, ni domestiques ni vraiment sauvages, qui évoluent dans des environnements « construits » par l'homme, constituant une part de cette "nature ordinaire» pour reprendre la formule de Laurent Godet. C'est cette relation entre environnements " construits " et modalités d'usage des espaces urbains par des non-humains qui est à la source du travail restitué dans ce poster. Il puise dans un premier travail de recherche de terrain mené sur l'habitat et les habitudes du pigeon à Paris, qui questionnait l'influence des structures urbaines sur le comportement de l'animal. Ce travail a par la suite été revisité et étendu 
dans le cadre d'un atelier de recherche appliquée mené par un groupe de six étudiants $\mathrm{du}$ Master de Géographie «Expertise, Concertation et Communication Environnementale » de Paris 8.

\section{BIBLIOGRAPHIE}

Godet L. (2010). « La "nature ordinaire" dans le monde occidental ». L’Espace Géographique, n 4, p. 295-308.

\section{AUTEUR}

\section{ANGELA CASAL}

LADYSS, Université Paris 8 